\title{
Biometry and ultrasound evaluation of testicles and accessory glands in Santa Ines rams
}

\author{
Mariana da Silva Ribeiro ${ }^{1 *}$, Celia Raquel Quirino², Aylton Bartholazzi Junior ${ }^{2}$, Aline Pacheco ${ }^{3}$ \\ ${ }^{1}$ Universidade Estadual do Norte Fluminense Darcy Ribeiro, Laboratório de Clínica e Cirurgia Animal, Campos dos Goytacazes, RJ, Brazil. \\ ${ }^{2}$ Universidade Estadual do Norte Fluminense Darcy Ribeiro, Laboratório de Reprodução e Melhoramento Genético Animal, Campos dos Goytacazes, \\ RJ, Brazil. \\ ${ }^{3}$ Universidade Federal do Oeste do Pará, Instituto de Biodiversidade e Floresta, Santarém, PA, Brazil.
}

\begin{abstract}
This work aimed to investigate the relationship between echogenicity, testicular biometry, and accessory gland biometry and evaluate the echogenicity pattern of these structures in Santa Ines rams. Fifty-four healthy Santa Ines sheep were classified into three age groups: group 1 - 3 to 5 months (pre-pubertal); group 2 - 7 to 11 months (pubertal); and group 3 - 13 to 28 months (sexually mature). The averages of testicular biometry and bulbourethral gland biometry were different among age groups. The testicular parenchyma was homogeneous with low echogenicity (pre-pubertal group) and medium echogenicity (pubertal and sexually mature groups), suggesting that testicular echogenicity can be a helpful tool to identify the start of puberty. The accessory glands were heterogeneous with low echogenicity in all age groups. Correlations were high between weight, biometry of testis and of bulbourethral gland and echogenicity of the accessory glands, indicating that sexually mature rams with higher body development have larger testicles and larger glands. We recommend the use of testicular biometry as a complementary evaluation of the reproductive efficiency of Santa Ines rams. The average values of echogenicity and the biometry of accessory glands are important parameters to assist the selection of breeding rams.
\end{abstract}

Key Words: ovine, semen, testicle, ultrasonography

\section{Introduction}

The selection of males with high reproductive capacity and high fertility is crucial to improve the reproductive performance of herds (Silva et al., 2002). In this context, it is extremely important to use auxiliary tools to attain greater reproductive and productive efficiency through the selection process.

The use of ultrasound in andrological examination of testicles of small ruminants has increased significantly (Andrade et al., 2014; Carazo et al., 2014; Cavalcante et al., 2014; Silva et al., 2015). Ultrasound is an effective technique because it is noninvasive and fast when used as a complementary biotechnology for reproductive assessment (Andrade et al., 2012).

Some authors (Pastore, 2008; Tapping and Cast, 2008; Cardilli et al., 2010) have suggested the use of testicular

Received: May 9, 2016

Accepted: December 17, 2016

*Corresponding author: mariana.ribeiroo@hotmail.com

http://dx.doi.org/10.1590/S1806-92902017000400007

How to cite: Ribeiro, M. S.; Quirino, C. R.; Bartholazzi Junior, A. and Pacheco, A. 2017. Biometry and ultrasound evaluation of testicles and accessory glands in Santa Ines rams. Revista Brasileira de Zootecnia 46(4):317-323.

Copyright (C 2017 Sociedade Brasileira de Zootecnia. This is an Open Access article distributed under the terms of the Creative Commons Attribution License (http://creativecommons.org/licenses/by/4.0/), which permits unrestricted use, distribution, and reproduction in any medium, provided the original work is properly cited. echogenicity as an alternative mechanism for selecting precocious animals. In addition, ultrasound can also be used accurately to examine the accessory glands in their normal orientation within the pelvic canal (Urt, 2014).

Despite its wide applicability in reproductive evaluation, there is subjectivity in the classification of the ultrasound image parameters and a lack of information concerning ultrasonography of the accessory glands in small ruminants. Since it is a qualitative evaluation, there is a loss of accuracy in determining the echogenicity and echo texture of the analyzed structure.

Thus, this study evaluated the morphology and echogenicity of testes and accessory glands in prepubertal, pubertal, and sexually mature Santa Ines rams using ultrasound. Furthermore, the relationship between echogenicity and biometry of testes and accessory glands in Santa Ines rams at different ages was analyzed.

\section{Material and Methods}

The experiment was performed in Campos dos Goytacazes, Rio de Janeiro, Brazil (Latitude 21 ${ }^{\circ} 45^{\prime} 40^{\prime \prime}$ S and Longitude $41^{\circ} 17^{\prime} 10^{\prime \prime}$ W). Fifty-four Santa Ines rams, clinically healthy, were classified into three age groups, according to sexual development: group 1 with 13 rams aged 3 to 5 months (pre-pubertal); group 2 with 28 rams 
aged 7 to 11 months (pubertal); and group 3 with 13 rams aged 13 to 28 months (sexually mature). The daily feed was composed of Tifton hay, star grass (Cynodon spp.), mineral salt, and water ad libitum.

Rams were considered in puberty when they were able to perform complete mating and there were spermatozoa with motility above $10 \%$ and concentration of at least $50 \times 10^{6}$ spermatozoa/mL (Wheaton and Godfrey, 2003). Animals were considered sexually mature when they had sexual instinct, mating ability, and sperm conditions consistent with full reproduction (Sasa et al., 2002).

First, the animals were weighed and scrotal circumference was measured. Height and width of testes were measured to calculate the total testicular volume (TV) by the cylinder volume formula (Fields et al., 1979): $\mathrm{TV}=2\left[\left(\mathrm{r}^{2}\right) \times \pi \times \mathrm{h}\right]$, in which $\mathrm{r}=$ radius, calculated from the width $(\mathrm{L} / 2) ; \pi=3.1416$; and $\mathrm{h}=$ mean testicular length or height.

A Mindray DP-2200 ultrasound apparatus coupled to a linear probe operating at frequency of $8.0 \mathrm{MHz}$ was used to evaluate testes and glands (Amorim, 2010), capturing 424 images.

The scrotum was shaved for the evaluation of echo texture and echogenicity of testicular parenchyma. The acoustic gel was placed on a linear probe and then precisely over the testicle region to be evaluated. Through scanning movements, images were obtained of the right and left testicular parenchyma using the following display planes: sagittal, frontal, and transversal (Figure 1).

Biometry (HRB - height of the right bulbourethral gland; HLB - height of the left bulbourethral gland; WRB - width of the right bulbourethral gland; and WLB - width of the left bulbourethral gland) and the evaluation of echotexture and echogenicity of vesicular and bulbourethral glands were carried out after rectal emptying. The images were obtained in the longitudinal plane using a linear transrectal probe.

The grayscale values were determined from each ultrasound image at the respective ages and expressed as units of pixel intensity. The ImageJ software was used to calculate the pixel intensity/area analyzed. The total range of pixel intensity was from zero to 255 (no subjective quantitative analysis), where zero was assigned to a totally black pixel (anechoic) and 255 was assigned to totally white pixel (hyperechoic). Thus, three areas were selected in each image, so that, later, the gray scale averages could be calculated for the following parameters: right testicular parenchyma echogenicity (RTE), left testicular parenchyma echogenicity (LTE), and total testicular parenchyma echogenicity (TTE); right bulbourethral gland echogenicity (RBE), left bulbourethral gland echogenicity (LBE), and total bulbourethral gland echogenicity (TBE); right vesicular gland echogenicity (RVE), left vesicular gland echogenicity (LVE), and total vesicular gland echogenicity (TVE).

The nomenclatures low echogenicity (0-85 pixels), moderate echogenicity (86-170 pixels), and high echogenicity (171-255 pixels) were used to describe the echogenicity of the evaluated structures.

The Santa Ines ram represented the experimental unit for all variables: testicular echogenicity (RTE, LTE, and TTE) and accessory glands echogenicity (RBE, LBE, TBE, RVE, LVE, and TVE) and ultrasound biometry of bulbourethral gland (HRB, HLB, WRB and WLB). Analysis of variance was used to verify the effect of age groups on variables using the PROC GLM of SAS (Statistical Analysis System, version 9.2). The statistical model used was: $\mathrm{Y}_{\mathrm{ij}}=\mu+\beta_{\mathrm{i}}+\mathrm{e}_{\mathrm{ij}}$, in which $\mathrm{Y}_{\mathrm{ij}}=$ dependent variable; $\mu=$ the overall mean for the variable; $\beta_{i}=$ the fixed effect of

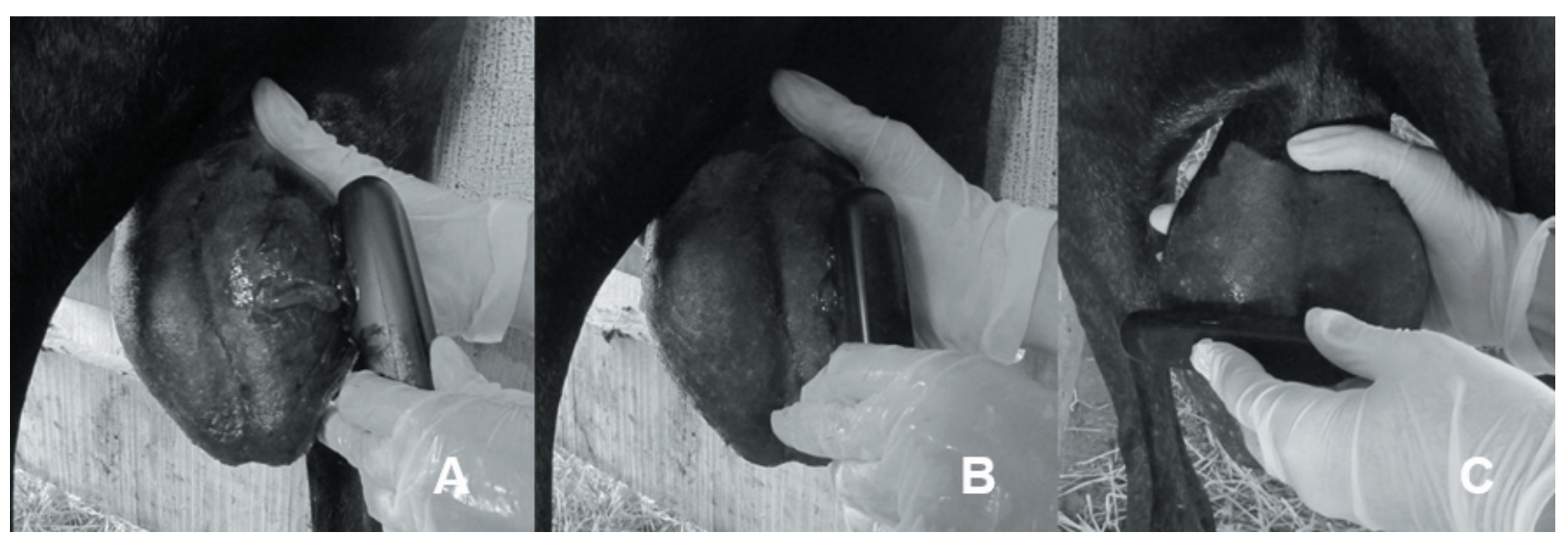

Figure 1 - Ultrasound examination of testicles in Santa Ines rams to obtain the images in (A) frontal, (B) sagittal, and (C) transversal plans. 
$i$-th age group; and $\mathrm{e}_{\mathrm{ij}}=$ experimental error associated with observation $\mathrm{Y}_{\mathrm{ij}}$, with normal distribution, mean zero, and variance $\sigma^{2}$. The means were compared by the SNK test at $5 \%$ significance. The CORR procedure of SAS was used to calculate the simple correlations among variables.

\section{Results}

There were differences $(\mathrm{P}<0.05)$ among age groups for testicular biometry, RTE, RBE, TBE, RVE, and LVE, biometry of bulbourethral gland, and weight. However, there was no difference $(\mathrm{P}>0.05)$ for LTE, TTE, and LBE.

Throughout the experiment, after the general clinical examination, no testicular abnormality was detected. The average weights were $27.83 \pm 2.54 \mathrm{~kg}$ (pre-pubertal group), $43.18 \pm 7.91 \mathrm{~kg}$ (pubertal group), and $70.23 \pm 10.51 \mathrm{~kg}$ (sexually mature group). The means of scrotal circumference (pre-pubertal group: $17.05 \pm 3.76 \mathrm{~cm}$; pubertal group: $29.23 \pm 3.32 \mathrm{~cm}$; sexually mature group: $33.23 \pm 1.60 \mathrm{~cm})$ and testicular volume (pre-pubertal group: $85.41 \mathrm{~cm}^{3}$; pubertal group: $479.23 \mathrm{~cm}^{3}$; sexually mature group: $760.66 \mathrm{~cm}^{3}$ ) were different among age groups, proportionally increasing with animal age.

The ultrasonographic pattern of the testicular parenchyma had homogeneous echo texture, independently of the evaluated group (Figure 2). The bulbourethral glands were located caudal to the urinary bladder and they were ovoid with variable echogenicity, which were bounded by a hyperechoic membrane (Figure 3). The vesicular glands were observed close to the urinary bladder colon, with irregular outline and surrounded by a membrane with higher echogenicity. The gland parenchyma had a heterogeneous
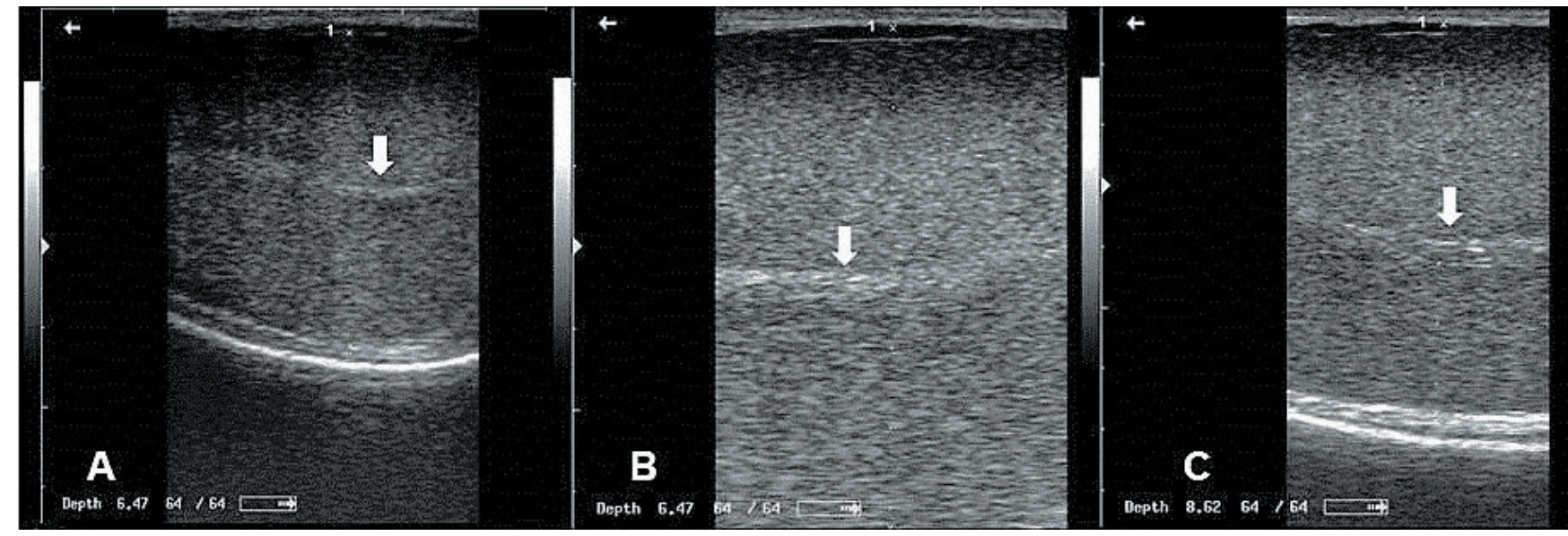

(A) Pre-pubertal, (B) pubertal, and (C) sexually mature groups in front plane, showing the testicular mediastinum (arrow).

Figure 2 - Ultrasound image of testicular parenchyma in Santa Ines rams.
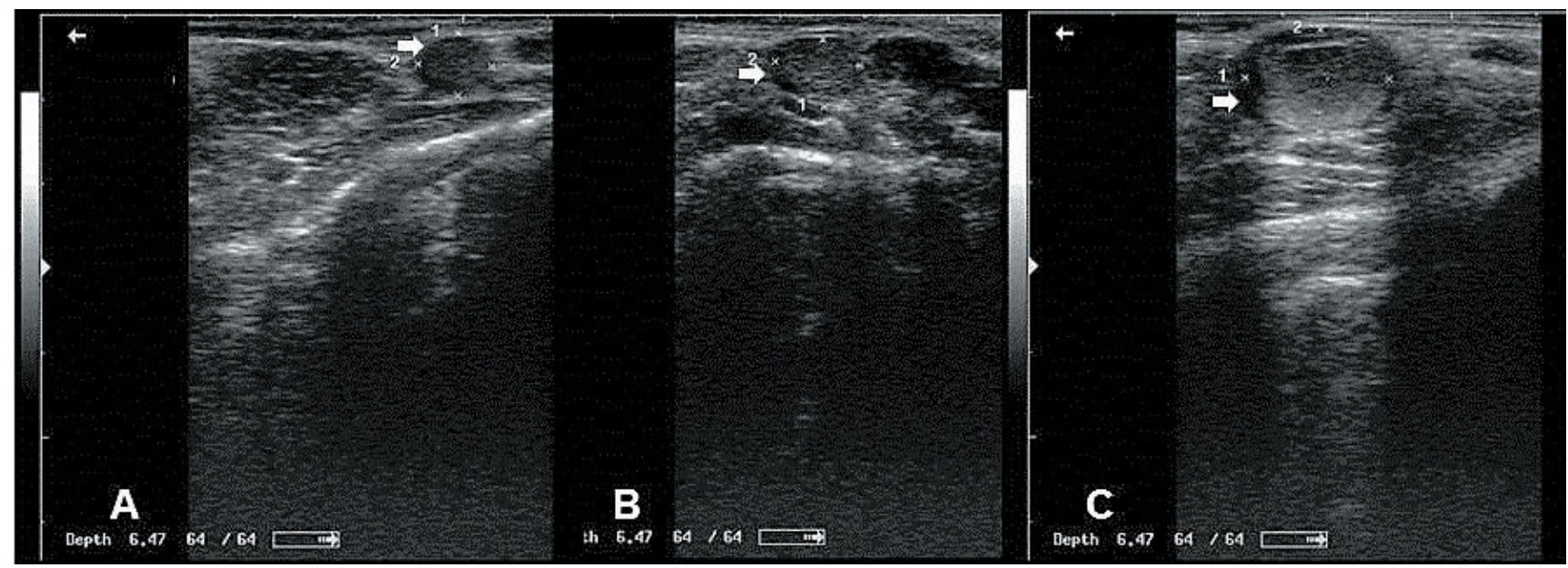

(A) pre-pubertal, (B) pubertal, and (C) sexually mature groups in longitudinal plane.

Figure 3 - Ultrasound images of bulbourethral gland (arrow) of Santa Ines rams. 
echotexture and low echogenicity (Figure 4). Furthermore, microcystic areas were observed in the gland parenchyma.

In general, the averages of RBE, TBE, RVE, LVE, and TVE were different among age groups. The sexually mature group showed the highest averages for these variables and the pre-pubertal group the smallest. The echogenicity of testicular parenchyma of pubertal animals increased compared with pre-pubertal animals. The averages of RTE were different between pre-pubertal and pubertal groups. However, the averages of LTE and TTE showed no difference. The averages of TTE were 85.23 pixels (pre-pubertal), 93.14 pixels (pubertal), and 86.78 pixels (sexually mature), ranging from low to moderate echogenicity (Table 1).

The averages of gland biometry were different among the age groups for all traits. The sexually mature group had the highest average and the pre-pubertal had the lowest (Table 2).

Weight had significant correlations of high magnitude with variables related to testis biometry, bulbourethral glands, and gland echogenicity (Table 3 ). Testicular volume had significant correlation of high magnitude with scrotal circumference (0.91). The correlations between testicular volume and the biometry of bulbourethral glands were high and significant. The scrotal circumference correlations were similar to those presented by testicular volume. The TTE had non-significant correlations of low magnitude (near zero) with all the characteristics analyzed. Total bulbourethral gland echogenicity and TVE had significant correlations from medium to high magnitude with weight, testicular biometry, and the ultrasonographic biometry of bulbourethral gland. The biometry of bulbourethral gland had significant correlations of high magnitude with weight, testicular volume, and scrotal circumference; medium to high magnitude with TBE and TVE; and high magnitude among them.

\section{Discussion}

The means of scrotal circumference for all groups were close to the values found in the literature (Souza, 2003; Pacheco et al., 2009). Souza (2003) demonstrated the tendency is for scrotal circumference of sheep to stop growing from 12 months of age, which was $32.09 \mathrm{~cm}$, similar to that found in the sexually mature animals.

Table 1 - Mean values and standard deviations of ultrasound variables of testicular echogenicity, bulbourethral gland echogenicity, and vesicular gland echogenicity of Santa Ines sheep, according to age group

\begin{tabular}{|c|c|c|c|}
\hline \multirow{2}{*}{$\begin{array}{l}\text { Ultrasound } \\
\text { variable } \\
\text { (pixels) }\end{array}$} & \multicolumn{3}{|c|}{ Age group } \\
\hline & $\begin{array}{c}\text { Group } 1 \\
\text { (3 to } 5 \text { months) }\end{array}$ & $\begin{array}{c}\text { Group } 2 \\
\text { ( } 7 \text { to } 11 \text { months) }\end{array}$ & $\begin{array}{c}\text { Group } 3 \\
\text { (13 to } 28 \text { months) }\end{array}$ \\
\hline RTE & $81.23 \pm 15.51 \mathrm{~B}$ & $94.14 \pm 10.48 \mathrm{~A}$ & $85.98 \pm 12.82 \mathrm{AB}$ \\
\hline LTE & $88.02 \pm 12.85 \mathrm{~A}$ & $92.09 \pm 12.51 \mathrm{~A}$ & $87.57 \pm 12.06 \mathrm{~A}$ \\
\hline TTE & $85.23 \pm 13.49 \mathrm{~A}$ & $93.14 \pm 10.14 \mathrm{~A}$ & $86.78 \pm 10.49 \mathrm{~A}$ \\
\hline $\mathrm{RBE}$ & $22.42 \pm 8.64 \mathrm{~B}$ & $28.33 \pm 11.29 \mathrm{~B}$ & $42.67 \pm 11.90 \mathrm{~A}$ \\
\hline LBE & $25.44 \pm 8.42 \mathrm{~A}$ & $25.74 \pm 8.64 \mathrm{~A}$ & $31.23 \pm 11.86 \mathrm{~A}$ \\
\hline TBE & $23.93 \pm 5.44 \mathrm{~B}$ & $27.04 \pm 8.69 \mathrm{~B}$ & $36.95 \pm 11.12 \mathrm{~A}$ \\
\hline RVE & $29.00 \pm 16.46 \mathrm{~B}$ & $41.01 \pm 18.07 \mathrm{~B}$ & $65.18 \pm 13.97 \mathrm{~A}$ \\
\hline LVE & $28.39 \pm 16.03 \mathrm{C}$ & $42.95 \pm 17.35 \mathrm{~B}$ & $55.44 \pm 15.33 \mathrm{~A}$ \\
\hline TVE & $28.69 \pm 14.71 \mathrm{C}$ & $41.98 \pm 15.38 \mathrm{~B}$ & $60.31 \pm 11.50 \mathrm{~A}$ \\
\hline
\end{tabular}

Group 1 - 3 to 5 months (pre-pubertal); group 2 - 7 to 11 months (pubertal); and group 3 - 13 to 28 months (sexually mature).

RTE - right testicular parenchyma echogenicity; LTE - left testicular parenchyma echogenicity; TTE - total testicular parenchyma echogenicity; RBE - righ bulbourethral gland echogenicity; LBE - left bulbourethral gland echogenicity; TBE - total bulbourethral gland echogenicity; RVE - right vesicular gland echogenicity; LVE - left vesicular gland echogenicity; TVE - total vesicular gland echogenicity.

Means followed by different letters in the same row indicate differences by SNK test at $5 \%$.
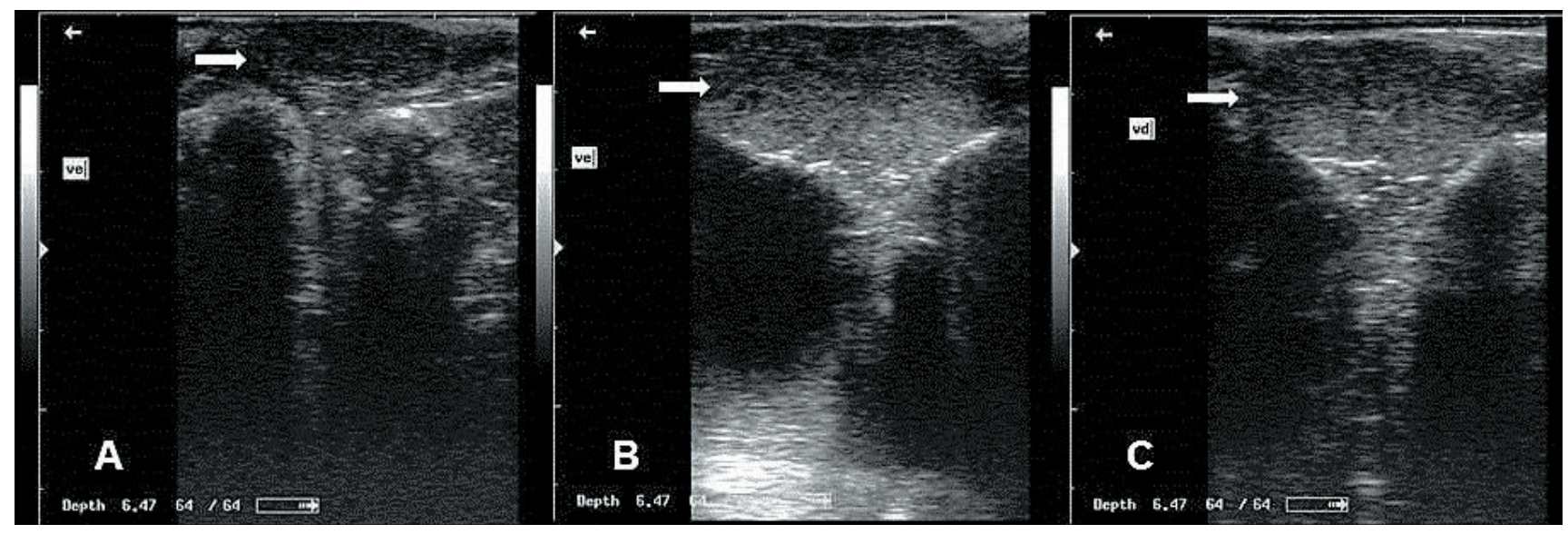

(A) Pre-pubertal, (B) pubertal, and (C) sexually mature groups in longitudinal plane.

Figure 4 - Ultrasound images of vesicular gland (arrow) of Santa Ines rams. 
Table 2 - Mean values and standard deviations of ultrasound biometry of bulbourethral gland of Santa Ines sheep according to age group

\begin{tabular}{lccc}
\hline & & \multicolumn{2}{c}{ Age group } \\
\cline { 2 - 4 } Ultrasound biometry & $\begin{array}{c}\text { Group 1 } \\
\text { (3 to 5 months) }\end{array}$ & $\begin{array}{c}\text { Group 2 } \\
\text { (7 to 11 months) }\end{array}$ & (13 to 28 months) \\
\hline Height of the right bulbourethral gland $(\mathrm{cm})$ & $0.72 \pm 0.14 \mathrm{C}$ & $0.97 \pm 0.12 \mathrm{~B}$ & $1.08 \pm 0.20 \mathrm{~A}$ \\
Height of the left bulbourethral gland $(\mathrm{cm})$ & $0.69 \pm 0.11 \mathrm{C}$ & $0.98 \pm 0.13 \mathrm{~B}$ & $1.10 \pm 0.14 \mathrm{~A}$ \\
Width of the right bulbourethral gland $(\mathrm{cm})$ & $1.02 \pm 0.17 \mathrm{C}$ & $1.33 \pm 0.16 \mathrm{~B}$ & $1.53 \pm 0.20 \mathrm{~A}$ \\
Width of the left bulbourethral gland $(\mathrm{cm})$ & $1.00 \pm 0.17 \mathrm{C}$ & $1.35 \pm 0.15 \mathrm{~B}$ & $1.55 \pm 0.16 \mathrm{~A}$ \\
\hline
\end{tabular}

Group 1 - 3 to 5 months (pre-pubertal); group 2 - 7 to 11 months (pubertal); and group 3 - 13 to 28 months (sexually mature).

Means followed by different letters in the same row indicate differences by SNK test at $5 \%$.

Table 3 - Pearson's correlation coefficient of weight, biometry, and echogenicity of testicle, vesicular gland, and bulbourethral gland of Santa Ines sheep

\begin{tabular}{|c|c|c|c|c|c|c|c|c|c|}
\hline & W & TV & $\mathrm{SC}$ & TTE & TBE & TVE & HRB & HLB & WRB \\
\hline $\mathrm{W}$ & - & & & & & & & & \\
\hline TV & $0.86^{* *}$ & - & & & & & & & \\
\hline $\mathrm{SC}$ & $0.76^{* *}$ & $0.91 * *$ & - & & & & & & \\
\hline TTE & -0.04 & 0.01 & 0.02 & - & & & & & \\
\hline TBE & $0.53 * *$ & $0.36^{* *}$ & $0.35^{*}$ & -0.22 & - & & & & \\
\hline TVE & $0.63 * *$ & $0.64 * *$ & $0.64 * *$ & -0.02 & 0.27 & - & & & \\
\hline HRB & $0.58 * *$ & $0.94 * *$ & $0.63 * *$ & -0.02 & $0.63^{* *}$ & $0.39 * *$ & - & & \\
\hline HLB & $0.62 * *$ & $0.92 * *$ & $0.68^{* *}$ & 0.18 & $0.55^{* *}$ & $0.50^{* *}$ & $0.81 * *$ & - & \\
\hline WRB & $0.66^{* *}$ & $0.95^{* *}$ & $0.71 * *$ & 0.00 & $0.37 * *$ & $0.49 * *$ & $0.70 * *$ & $0.72 * *$ & - \\
\hline WLB & $0.77 * *$ & $0.93 * *$ & $0.82 * *$ & 0.17 & $0.44 * *$ & $0.53 * *$ & $0.63 * *$ & $0.72 * *$ & $0.83^{* *}$ \\
\hline
\end{tabular}

W - weight; TV - testicular volume; SC - scrotal circumference; TTE - total testicular echogenicity; TBE - total bulbourethral gland echogenicity; TVE - total vesicular gland echogenicity; HRB - height of the right bulbourethral gland; HLB - height of the left bulbourethral gland; WRB - width of the right bulbourethral gland; WLB - width of the left bulbourethral gland.

$* \mathrm{P}<0.05$.

$* * \mathrm{P}<0.01$.

The average value of testicular volume of pre-pubertal group was lower than that found by Pacheco (2008), in which the mean value was $133.97 \mathrm{~cm}^{3}$. However, the animals of pubertal group showed higher average than that reported by the same author $\left(429.55 \mathrm{~cm}^{3}\right)$ in 7 to 12 month-old Santa Ines sheep. Camela (2015) observed a lower value (approximately $728.33 \mathrm{~cm}^{3}$ ) from that found in the present study while evaluating this parameter in mature Dorper sheep.

Comparing averages of RTE and LTE in the different groups, they presented pixel quantities close to each other. These findings are consistent with those reported by Lavoipierre (2000) and Silva et al. (2015), according to which, the testicular parenchyma has a homogeneous echo texture; then, if both antimeres do not have the same echogenicity, disease should be suspected.

The TTE ranged from low to moderate echogenicity among age groups. These results were similar to those found by Gouletsou et al. (2003), Amorim (2010), Andrade et al. (2012), and Andrade et al. (2014). Silva et al. (2015) observed values lower than those found in pre-pubertal and pubertal groups, which were near 70.20 pixels ( 3 to 6 months old) and 91.44 pixels (7 to 12 months old) for crossbred sheep. However, these authors found an average near 112.84 pixels in 13 to 18 month-old sheep, which was higher than that found in the sexually mature group.

The averages of TTE in pubertal and sexually mature groups were lower than the average presented by Urt (2014), which was 108.9 pixels in 10-12 month-old Texel sheep. According to this author, this average corresponds to a testicular parenchyma with moderate echogenicity.

Andrade et al. (2014) compared the testicular parenchyma of pre-pubertal and pubertal Santa Ines sheep, finding predominance of low echogenicity images in prepubertal animals and moderate echogenicity images in pubertal animals. Thus, they demonstrated the importance of sonographic evaluation of testicles, especially the study of testicular echogenicity, to assist in puberty identification of sheep and select animals with greater reproductive precocity.

In the study by Camela (2015) with Dorper sheep, the parenchyma of the bulbourethral gland presented heterogeneous echo texture and mixed echogenicity. These structures showed low echogenicity in the present work, which was similar to that observed by Jucá et al. (2011) in Santa Ines sheep. 
The echo texture and echogenicity of the vesicular gland parenchyma in the present study were similar to those reported by Jucá et al. (2009) and Teixeira et al. (2013). The microcystic areas, observed in the present study, are described as vesicles that have become filled with fluid before ejaculation, which will form the seminal plasma (Gartner and Hiatt, 2003). Camela (2015) noted that these vesicles have a reduced quantity of liquid after ejaculation. However, regardless of the moment of assessment (before or after ejaculation), this gland predominantly appeared as high intensity hypoechoic, similar to that reported by Jucá (2005).

Jucá et al. (2009) classified echogenicity of the bulbourethral glands and the vesicle glands in pre-ejaculate as low-intensity hypoechoic. The use of quantitative evaluation to determine the testicular echogenicity and the accessory gland echogenicity with the aid of ImageJ software, through the analysis of mean values of pixels, can overcome the subjectivity of ultrasonographic evaluation of these structures by making it more accurate. However, there is a lack of studies using this technique, especially to assess bulbourethral and vesicular glands in sheep. Moreover, these values can be helpful for other researchers and technicians to determine the normal range when evaluating ultrasound images of Santa Ines sheep.

Jucá et al. (2009), studying measures of the accessory glands in 18, 30, and 48 month-old Santa Ines sheep, observed a significant difference among ages. Animals with 18 months of age had mean bulbourethral gland height $(1.158 \pm 0.035 \mathrm{~cm})$ close to the values found in the present study in sexually mature animals $(1.08$ and $1.10 \mathrm{~cm}$ for height of the right and of the left bulbourethral gland, respectively). The average height of bulbourethral glands in animals with 18 months old $(1.158 \pm 0.035 \mathrm{~cm})$ was close to those of sexually mature group $(1.08$ and $1.10 \mathrm{~cm}$ for height of the right and of the left bulbourethral gland, respectively).

Camela (2015) estimated the average dorsal-ventral and cranio-caudal distances of the bulbourethral gland in Dorper sheep, which were $1.372 \mathrm{~cm}$ in pubertal animals (8 to 11 months) and $1.471 \mathrm{~cm}$ in mature animals ( $>12$ months). These values were higher than the average observed in the present study.

There are few papers regarding echogenicity and measurements of vesicular and bulbourethral glands in sheep. Therefore, the findings of this study are important, especially those regarding pre-pubertal sheep (3 to 5 months), since echogenicity and measurements of glands have high correlations with testis size and weight. Thus, at this age it would be possible to select animals with greater sexual precocity.
In relation to the association among the traits, similar correlation results of weight with testis biometry were found by Alves et al. (2006), suggesting that the scrotal circumference is a parameter that can complement others in selection by breeders.

Testicular volume and scrotal circumference correlations had high magnitude (near 1), indicating that both characteristics can be used to aid in selection of future breeders, since they significantly correlated with weight. According to Unanian et al. (2000), testicular volume can be used to select young animals for future breeders, as scrotal circumference also can. The combination of these characteristics should enable a more precise prediction of the breeding potential. However, since scrotal circumference measurement is very practical and easy to perform, we suggest implementing this.

The high correlations between echogenicity of accessory glands and weight, testicular biometry and the ultrasonographic biometry suggested that heavier animals tend to have larger testes, larger glands, and consequently, greater echogenicity.

The correlations found between the biometry of the bulbourethral gland and scrotal circumference are similar to those reported by Camela (2015), which were significant and of medium magnitude $(0.543 ; \mathrm{P}<0.01)$.

Although some authors have studied testicular echogenicity of healthy sheep (Amorim, 2010; Teixeira et al., 2011; Andrade et al., 2012; Urt, 2014), few have developed studies involving ultrasound biometry of the bulbourethral glands in Santa Ines sheep, especially in pre-pubertal, pubertal, and sexually mature animals and correlated biometrics with all the variables presented in this study.

\section{Conclusions}

The values of echogenicity and biometry of accessory glands can be used as complementary parameters to assist in the selection of rams with greater sexual precocity. In addition, more detailed ultrasound assessment of the reproductive organs of males can help in the diagnosis of testicular parenchyma diseases of adult rams, which can lead to subfertility.

\section{Acknowledgments}

We thank the group of PROVIN (Extension Project in Production and Sheep Selection of UENF) for providing the animals and UENF for contributing with financial support. 


\section{References}

Alves, J. M.; McManus, C.; Lucci, C. M.; Carneiro, H. C. R.; Dallago, B. S.; Cadavid, V. G.; Marsiaj, P. A. P. and Louvandini, H. 2006. Estação de nascimento e puberdade em cordeiros Santa Inês. Revista Brasileira de Zootecnia 35:958-966.

Amorim, A. K. G. A. 2010. Ultrassonografia dos testículos e epidídimos de carneiros jovens na fase peri-puberal. Dissertação (M.Sc.). Universidade Federal Rural de Pernambuco, Recife.

Andrade, A. K. G.; Soares, A. T.; Cartaxo, F. Q.; Peña-Alfaro, C. E. and Guerra, M. M. P. 2012. Achados ultrassonográficos nos testículos e epidídimos de carneiros deslanados jovens e clinicamente sadios. Arquivo Brasileiro de Medicina Veterinária e Zootecnia 64:371-379.

Andrade, A. K. G.; Soares, A. T.; Freitas, F. F.; Silva, S. V.; PeñaAlfaro, C. E.; Batista, A. M. and Guerra, M. M. P. 2014. Testicular and epididymal ultrasonography in Santa Inês lambs raised in Brazil. Animal Reproduction 11:110-118.

Camela, E. S. C. 2015. Ultrassonografia de glândulas genitais acessórias em carneiros da raça Dorper - caracterização e correlações reprodutivas. Dissertação (M.Sc.). Universidade Estadual Paulista, Faculdade de Ciências Agrárias e Veterinárias, Jaboticabal.

Carazo, L. R. B.; Guimarães, J. D.; Machado, T. P.; Machado, T. P. L. C.; Oliveira, F. A. S. A. M. and Pereira, D. B. 2014. Ultrassonografia testicular em caprinos jovens da raça Alpina. Arquivo Brasileiro de Medicina Veterinária e Zootecnia 66:388-394.

Cardilli, D. J.; Toniollo, G. H.; Pastore, A. A.; Canola, J. C.; Mercadante, M. E. Z. and Oliveira, J. A. 2010. Padrão ultrassonográfico do parênquima, mediastino e túnicas testiculares em bovinos jovens da raça Nelore. Ciência Animal Brasileira 11:899-905.

Cavalcante, J. M. M.; Brasil, O. O.; Oliveira, R. V.; Pessoa, A. W. P.; Araujo, A. A. and Nunes, J. F. 2014. Ultrassonografia testicular em caprino com degeneração testicular associado a lesões escrotais: Relato de caso. Revista Brasileira de Higiene e Sanidade Animal 8:54-72.

Fields, M. J.; Burns, W. C. and Warnick, A. C. 1979. Age, season and breed effects on testicular volume and semen traits in young beef bulls. Journal of Animal Science 48:1299-1304.

Gartner, L. P. and Hiatt, J. L. 2003. Tratado de histologia em cores. 2.ed. Editora Guanabara Koogan S. A., Rio de Janeiro. p.414-416.

Gouletsou, P. G.; Amiridis, G. S.; Cripps, P. J.; Lainas, T.; Deligiannis, K.; Saratsis, P. and Fthenakis, G. C. 2003. Ultrasonographic appearance of clinically healthy testicles and epididymis of rams. Theriogenology 59:1959-1972.

Jucá, A. F. 2005. Avaliação ultra-sonográfica dos testículos e das glândulas sexuais acessórias de ovinos da raça Santa Inês. Dissertação (M.Sc.). Universidade Federal da Bahia, Escola de Medicina Veterinária, Salvador.

Jucá, A. F.; Moura, J. C. A.; Gusmão, A. L.; Bittencourt, T. C.; Nascimento, M. C. and Barbosa, C. M. P. 2009. Avaliação ultrassonográfica dos testículos e das glândulas sexuais anexas de carneiros Santa Inês. Ciência Animal Brasileira 10:650-659.

Jucá, A. F.; Pinto, L. F. B.; Moita, A. K. F.; Oliveira, R. J. F.; Melo Filho, G. M.; Santos, L. B.; Fiuza, M. S. and Azevedo, H. C. 2011.
Ecotextura testicular por ultrassonografia em ovinos Santa Inês. In: Anais do 21ํㅡㄹ Congresso Brasileiro de Zootecnia, Maceió.

Lavoipierre, A. M. 2000. Ultrasound of the prostate and testicles. World Journal Surgery 24:198-207.

Pacheco, A. 2008. Comportamento sexual, idade à puberdade e parâmetros reprodutivos de machos ovinos da raça Santa Inês. Tese (D.Sc.). Universidade Estadual do Norte Fluminense Darcy Ribeiro, Campos dos Goytacazes.

Pacheco, A.; Oliveira, A. F. M.; Quirino, C. R. and Landim, A. V. 2009. Características seminais de carneiros da raça Santa Inês na pré-puberdade, puberdade e na pós-puberdade. Ars Veterinaria 25:90-99.

Pastore, A. A. 2008. Ultra-sonografia na avaliação andrológica de bovinos da raça Nelore. Tese (D.Sc.). Universidade Estadual Paulista "Júlio Mesquita Filho", Faculdade de Ciências Agrárias e Veterinárias, Jaboticabal.

Sasa, A.; Teston, D. C.; Rodrigues, P. A.; Coelho, L. A. and Schalch, E. 2002. Concentrações plasmáticas de progesterona em ovelhas lanadas e deslanadas no período de abril a novembro, no Estado de São Paulo. Revista Brasileira de Zootecnia 31:1150-1156.

Silva, E. G.; Gonçalves, M. T. C.; Pinto, S. C. C.; Soares, D. M.; Oliveira, R. A.; Alves, F. R.; Araújo, A. V. C. and Guerra, P. C. 2015. Análise quantitativa da ecogenicidade testicular pela técnica do histograma de ovinos da baixada ocidental maranhense. Pesquisa Veterinária Brasileira 35:297-303.

Silva, A. E. D. F.; Unanian, M. M.; Cordeiro, C. M. T. and Freitas, A. R. 2002. Relação da circunferência escrotal e parâmetros da qualidade do sêmen em touros da raça Nelore, PO. Revista Brasileira de Zootecnia 31:1157-1165.

Souza, C. E. A. 2003. Avaliação da função reprodutiva de carneiros Santa Inês durante o primeiro ano de vida: estudo do desenvolvimento testicular, produção espermática e caracterização das proteínas do plasma seminal. Dissertação (M.Sc.). Universidade Federal do Ceará, Fortaleza.

Tapping, C. R. and Cast, J. E. 2008. Scrotal ultrasound: a pictorial review. Ultrasound 16:226-233.

Teixeira, P. P. M.; Cardilli, D. J.; Paz, C. C.; Campos, G. S.; Coutinho, L. N.; Barros, F. F. P. C. and Padilha, L. C. 2013. Anatomofisiologia do sistema reprodutivo masculino. p.12. In: Biotécnicas reprodutivas em caprinos e ovinos. Oliveira, M. E. F.; Teixeira, P. P. M. and Vicente, W. R. R., eds. MedVet, São Paulo.

Teixeira, P. P. M.; Oliveira, M. E. F.; D’Amato, C. C.; Rodrigues, L. F. S. and Vicente, W. R. R. 2011. Avaliação ultrassonografia da ecogenicidade do parênquima testicular como exame complementar no andrológico de carneiros. Nucleus Animalium 3:31-36.

Unanian, M. M.; Silva, A. E. D. F.; McManus, C. and Cardoso, E. P. 2000. Características biométricas testiculares para avaliação de touros Zebuínos da raça Nelore. Revista Brasileira de Zootecnia 29:136-144.

Urt, M. A. G. 2014. Ecotextura testicular e qualidade seminal em ovinos da raça Texel. Tese (D.Sc.). Universidade Federal de Mato Grosso do Sul, Campo Grande, MS.

Wheaton, J. E. and Godfrey, R. W. 2003. Plasma LH, FSH, testosterone, and age at puberty in ram lambs actively immunized against an inhibin a-subunit peptide. Theriogenology 60:933-941. 